\title{
The Low Dose Streptozotocin Murine Model of Type 1 (Insulin-Dependent) Diabetes Mellitus: Studies In Vivo and In Vitro of the Modulating Effect of Sex Hormones
}

\author{
H. Kromann ${ }^{1}$, M. Christy ${ }^{1}$, Å. Lernmark ${ }^{2}$, M. Nedergaard ${ }^{1}$ and J. Nerup \\ ${ }^{1}$ Steno Memorial Hospital and ${ }^{2}$ Hagedorn Research Laboratory, Gentofte, Denmark
}

\begin{abstract}
Summary. The influence of sex on pancreatic islet B cell susceptibility to streptozotocin was studied in mice given multiple low doses of streptozotocin. Male C3 D2 F1 mice developed a steadily increasing blood glucose level after a lag period of about 3 weeks, in contrast to females who were resistant. Spleen cells from streptozotocin treated female animals produced hyperglycaemia in total body irradiated syngeneic female recipients, but only if the recipients were treated with testosterone. Testosterone treatment of donors did not affect blood glucose levels of recipients. Streptozotocin cytotoxicity in vitro determined by a ${ }^{51} \mathrm{Cr}$-release assay revealed an increased sensitivity to streptozotocin in dispersed islet cells from adult male animals as compared with cells from adult female mice. The incubation of islet cells from animals of either sex with testosterone, or oestradiol plus progesterone, did not enhance the susceptibility to streptozotocin. Islet cells from sexually immature male or female mice were less susceptible to streptozotocin. The results demonstrate that sex determines susceptibility to streptozotocin in vivo and in vitro.
\end{abstract}

Key words: Mouse, experimental diabetes, streptozotocin, sex influence, sex hormone, islet cell cytotoxicity in vitro, lymphocyte transfer.

The incidence of Type 1 (insulin-dependent) diabetes mellitus is influenced by sex. From mortality studies before the insulin era a male preponderance was observed mainly in the age group 10-30 years [1]. In accordance with this, incidence studies demonstrated more boys developing Type 1 diabetes in age groups $0-4$ an $11-15$ years [2], $10-20$ years [3] and $15-19$ years [4]. Sex may also influence the development of diabetes in experimental animals since male rats became diabetic more readily than female rats after subtotal pancreatectomy [5]. Encephalomyocarditis virus induces a pronounced diabetogenic action in certain strains of mice, the females, however, being resistant [6]. Multiple low-dose injections of the diabetogenic drug streptozotocin (SZ) [7] has been shown to produce diabetes in male mice but not in females or castrated males [8]. Furthermore, a single injection of the same drug can produce severe diabetes in male mice, whereas females remain euglycaemic [9].

We confirmed the results of Rossini et al. [8] and furthermore have demonstrated the influence of sex on isolated B cells in vitro [10]. It was not clear, however, whether the influence of sex was due to a direct effect on the B cells. In the present study, therefore, we have extended our experiments in vitro to include islet cells from sexually immature animals as well as islet cells incubated in the presence of different sex hormones.

Transfer experiments suggest that the induction of diabetes by multiple low doses of SZ is a lymphocyte dependent phenomenon [11-14]. To test whether such cell-mediated B cell damage is influenced by sex hormones, we have transferred spleen cells from $\mathrm{SZ}$ treated female mice to syngeneic total body irradiated female recipients after treating either the donors or recipients, or both, with testosterone.

\section{Materials and Methods}

\section{Experiments In Vivo}

Ten-week-old C3 D2 Fl (DBA/2 J male $\times$ C3H/Tif female) mice (Gl. Bomholtgård, Ry, Denmark) of both sexes were caged in groups of four or five with free access to water and standard mouse chow (Rostock mixture, Korn og Foderstof Kompagniet, Viby, Denmark). The F1 hybrid strain was chosen since it was previously shown to respond reproducibly and characteristically in the low dose SZ model [10]. At 08.00 to $10.00 \mathrm{~h}$ the animals were given five daily IP injections of SZ (40 mg/ $\mathrm{kg}$, Lot Nos. 60140 and U 9889, Upjohn, Kalamazoo, Michigan, USA) dissolved in saline immedi- 


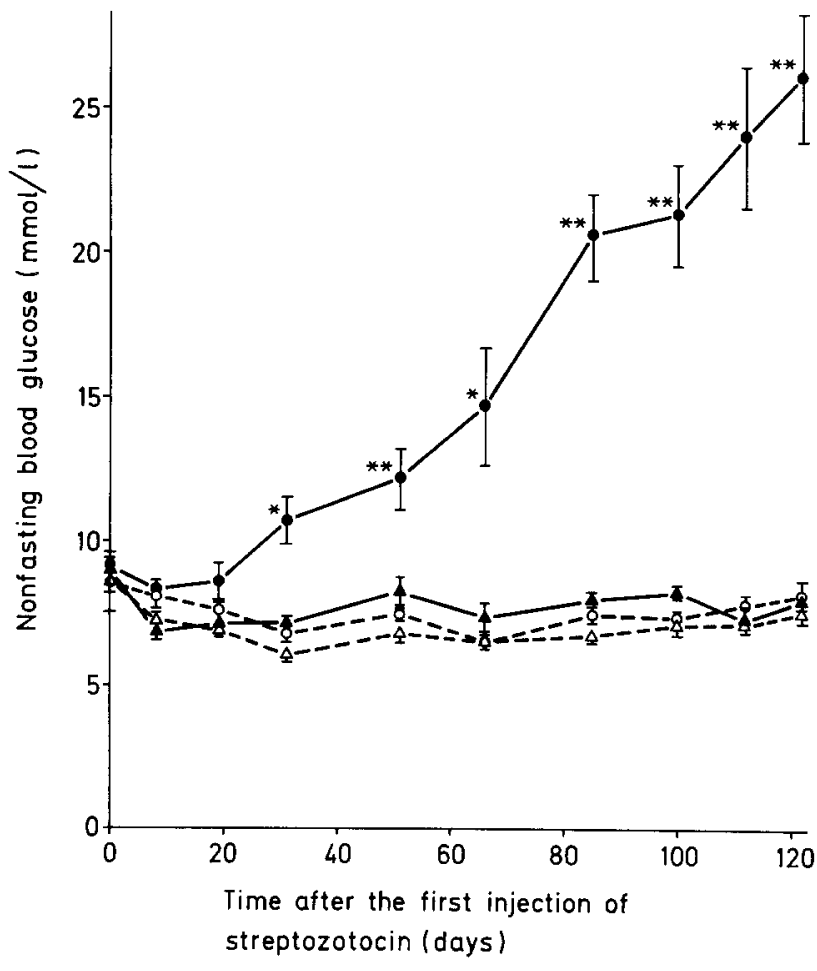

Fig. 1. Non-fasting blood glucose levels (mean $\pm \mathrm{SEM}$ ) in seven male (•) and eight female ( $\Delta$ ) C3 D2 F1 mice following five daily injections of streptozotocin $(40 \mathrm{mg} / \mathrm{kg})$. Eight males (o) and eight females $(\triangle)$ were injected with the solvent only. Streptozotocin induced elevation of blood glucose levels in males $\left({ }^{*} p<0.01\right.$; $* * *<0.001$ ) whereas no differences were observed between female test and control animals

ately before use. The controls received saline only. Non-fasting blood glucose was measured frequently at 09.00 to $10.00 \mathrm{~h}$ from days $0-22$ in samples taken from the retro-orbital venous plexus [15].

\section{Transfer Experiments}

Ten-week-old female C3 D2 F1 mice were caged in groups of five. Half of the animals were selected to be donors and were treated with $\mathrm{SZ}$ or saline as above. Simultaneously with the first SZ/saline injection the animals were injected SC with ground-nut-oil ( $100 \mu \mathrm{l}$, with or without $1 \mathrm{mg}$ testosterone, DAK, Denmark).

All recipient mice were total body irradiated 10 days later with $400 \mathrm{rad} /$ animal in a Siemens Stabilipan therapy machine operated at $200 \mathrm{kv}$ and $16 \mathrm{~mA}$ with $0.9-\mathrm{mm} \mathrm{Cu}$ and $0.5-\mathrm{mm} \mathrm{Al} \mathrm{filtration,} \mathrm{and}$ thereafter injected with ground-nut-oil with or without $1 \mathrm{mg}$ testosterone. Two to three hours after the irradiation, which reduced leucocyte numbers in peripheral blood from approximately 8000 to $800 / \mu \mathrm{l}$ (unpublished observation), each recipient received $2 \times 10^{7}$ spleen cells prepared from the donors by squeezing the spleens through a nylon net with rough meshes. Non-fasting blood glucose was measured at frequent intervals. Ten days after the spleen cell transfer an IP glucose tolerance test (1 g glucose $/ \mathrm{kg}$; blood glucose at 0,10 and $60 \mathrm{~min}$ ) was performed [15].

\section{Studies In Vitro}

Suspensions of islet cells from 2 or 10 week-old C3 D2 F1 mice were prepared as described previously [16]. Briefly, islets of Langerhans were individually selected after collagenase digestion of eight to ten pancreas, and cell suspensions containing $82 \%-88 \%$ B cells were obtained by the combined use of Dispase digestion, calcium depletion and mechanical treatment. The cells were labelled with $0.5-1 \mathrm{cpm} / \mathrm{cell}$ of ${ }^{51} \mathrm{Cr}$ and incubated at $37^{\circ} \mathrm{C}$ in a humidified atmosphere of $95 \% \mathrm{O}_{2} / 5 \% \mathrm{CO}_{2}$ in $195 \mu 1$ of Roswell Park Memorial Institute (RPMI) 1640 medium (Flow Laboratories, Irvine, UK) supplemented with $2 \mathrm{~g} / 1 \mathrm{NaHCO}_{3}, 2 \mathrm{mmol} / \mathrm{l}$ glutamine, $100 \mathrm{IU} / \mathrm{ml}$ penicillin and $100 \mu \mathrm{g} / \mathrm{ml}$ streptomycin and $20 \%(\mathrm{v} / \mathrm{v})$ newborn calf serum (Lot no. 453106, Flow Laboratories, Irvine, UK). The calf serum was heat inactivated at $56^{\circ} \mathrm{C}$ for $30 \mathrm{~min}$.

In each experiment, cell suspensions containing approximately $10^{4}$ cells/well, in duplicate or triplicate determinations, were incubated in parallel either with or without SZ $(1.0-37.5 \mathrm{mmol} / 1$, final concentrations). A stock solution of SZ in ice-cold $\mathrm{HCl}(10 \mathrm{mmol} / 1)$ was prepared immediately before use and $5 \mu 1$ aliquots were added to the cells at the start of the incubations to final concentrations as indicated. Control cells received $\mathrm{HCl}(10 \mathrm{mmol} / \mathrm{l})$ only. Addition of $\mathrm{HCl}(5 \mu \mathrm{l})$ to test or control cells $(195 \mu \mathrm{l})$ did not affect the $\mathrm{pH}$ of the tissue culture medium. Testosterone (Lot no. $106 \mathrm{C}-0374$ ), or $\beta$ oestradiol (Lot no. C-0519) and progesterone (Lot no.95 C-0320), (all from Sigma Chemical Company, Montana, USA) were dissolved in ethanol, the ethanol evaporated and the tissue culture medium added immediately before complete dryness to give final concentrations of $10 ; 1$ and $10 \mu \mathrm{g} / \mathrm{ml}$ respectively. Control cells were supplemented in the same way but without the addition of sex hormones, and the wells containing $200 \mu \mathrm{l}$ media were incubated at $37^{\circ} \mathrm{C}$. After $4 \mathrm{~h}, 2 \mathrm{ml}$ of RPMI 1640 medium was added. The cells were spun for $5 \mathrm{~min}(50 \times \mathrm{g})$ and $2 \mathrm{ml}$ of the supernatants were counted in an automatic gammacounter. Cells incubated with $5 \%$ (v/v) Triton X-100 (iso-octylphenoxypolyethoxyethanol (Packard Instruments, Illinois, USA)) were considered to release maximal releasable amount of the isotope. In 66 experiments the release from cells incubated without SZ (controls) was $26.9 \pm 7.0 \%$ (mean $\pm \mathrm{SD}$ ) calculated as

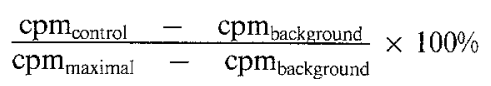

and without differentiation between cells from male or female mice or cells from immature or mature animals. Results are presented as specific release of ${ }^{51} \mathrm{Cr}$ calculated in individual experiments as

$\frac{\mathrm{cpm}_{\mathrm{SZ}}-\mathrm{cpm}_{\text {control }}}{\mathrm{cpm}_{\text {maximal }}-c p m_{\text {background }}} \times 100 \%$

\section{Evaluation of Results}

The results are expressed as mean \pm SEM for the number of experiments or animals shown. The significance of differences were tested by Wilcoxon's two-sample location test, one-sided if previous studies indicated a certain alternative hypothesis to the nul-hypothesis.

\section{Results}

\section{Experiments In Vivo}

Male mice treated with $40 \mathrm{mg} / \mathrm{kg} \mathrm{SZ}$ for 5 days developed hyperglycaemia after 3 weeks. The blood glucose level steadily increased throughout the study period, while all female mice remained euglycaemic (Fig. 1). 
Table 1. Protocol and results of spleen cell transfer experiments in female mice

\begin{tabular}{|c|c|c|c|c|c|c|c|c|}
\hline \multirow[t]{3}{*}{ Experimental group } & \multirow{2}{*}{\multicolumn{2}{|c|}{$\frac{\text { Donors }}{\text { Treatment }}$}} & \multicolumn{6}{|c|}{ Recipients } \\
\hline & & & \multicolumn{2}{|c|}{ Treatment } & \multicolumn{3}{|c|}{ Non-fasting blood glucose after transfer $(\mathrm{mmol} / \mathrm{l})$} & \multirow{2}{*}{$\frac{\text { GTT }}{\text { Day } 10}$} \\
\hline & $\mathrm{SZ}$ & Test. & Rad. & Test. & Day 0 & Day 3 & Day 6 & \\
\hline A & 0 & 0 & + & 0 & $7.9 \pm 0.2$ & $7.9 \pm 0.5$ & $8.3 \pm 0.2$ & $694 \pm 31$ \\
\hline B & 0 & 0 & + & + & $6.9 \pm 0.4$ & $7.2 \pm 0.2$ & $7.6 \pm 0.3$ & $671 \pm 21$ \\
\hline $\mathrm{C}$ & + & 0 & + & 0 & $8.2 \pm 0.2$ & $8.1 \pm 0.1$ & $7.9 \pm 0.3$ & $633 \pm 24$ \\
\hline $\mathrm{D}$ & + & + & + & 0 & $8.0 \pm 0.2$ & $7.9 \pm 0.2$ & $8.4 \pm 0.4$ & $714 \pm 25$ \\
\hline $\mathrm{E}$ & + & 0 & + & + & $8.4 \pm 0.4$ & $9.1 \mp 0.3$ & $9.2 \pm 0.3$ & $737 \pm 16$ \\
\hline $\mathrm{F}$ & + & + & + & + & $6.4 \pm 0.3$ & $8.9 \pm 0.2$ & $9.6 \pm 0.4$ & $792 \pm 13$ \\
\hline
\end{tabular}

Each experimental group consisted of five donors and five recipients. Donors received five daily injections of streptozotocin (SZ) $40 \mathrm{mg} / \mathrm{kg}$ $(+)$ or saline $(0)$ and on the first day an additional injection of testosterone (Test., $1 \mathrm{mg}$ ) as indicated. Spleen cell transfer was performed 10 days after the first SZ injection into total body irradiated (Rad., $400 \mathrm{rad}$ ) recipients, some of which also received an injection of testosterone $(1 \mathrm{mg})$ as indicated. Animals not injected with testosterone were injected with solvent only. Non-fasting blood glucose levels (mean \pm SEM) $2 \mathrm{~h}$ before spleen cell transfer on day 0 are shown together with post-transfer levels on two occasions. Group E demonstrated higher blood glucose levels after the transfer than group $\mathrm{B}(p<0.001, p<0.03)$ as did group $\mathrm{F}(p<0.01, p<0.01)$. Areas under the blood glucose curve during an IP glucose tolerance test (GTT, arbitrary units) showed higher values in groups E and $\mathrm{F}$ as compared with group B ( $p<0.03$ and $p=0.004$ respectively)

\section{Transfer Experiments}

Female donor mice treated with SZ and/or testosterone did not develop hyperglycaemica in the 10-day period until sacrifice (data not shown). Recipients remained euglycaemic when transferred with spleen cells from controls, SZ treated donors or SZ plus testosterone treated donors (Table 1). Recipients treated with testosterone, however, demonstrated elevation of the blood glucose level 3 and 6 days after the transfer of spleen cells from SZ treated donors. No additional effect was obtained by testosterone treatment of the donors.

An IP glucose tolerance test, performed 10 days after the transfer, demonstrated a greater area under the blood glucose curve in testosterone treated recipients transferred with spleen cells from SZ treated donors (group E) or SZ plus testosterone treated donors (group F) as compared with testosterone treated recipients treated with spleen cells from controls (group B). The areas under the blood glucose curves were similar in recipients transferred with spleen cells from controls (group A), SZ treated donors (group C) and SZ plus testosterone treated donors (group D). Non-fasting blood glucose levels estimated 13-28 days after the transfer demonstrated no elevations in any group.

\section{Experiments In Vitro}

Incubation with SZ $(7.5 \mathrm{mmol} / \mathrm{l})$ for $4 \mathrm{~h}$ induced a specific ${ }^{51} \mathrm{Cr}$ release of $15.2 \pm 2.5 \%(n=13)$ from sexually mature male mice islet cells, whereas the specific release from sexually mature female mice islet cells

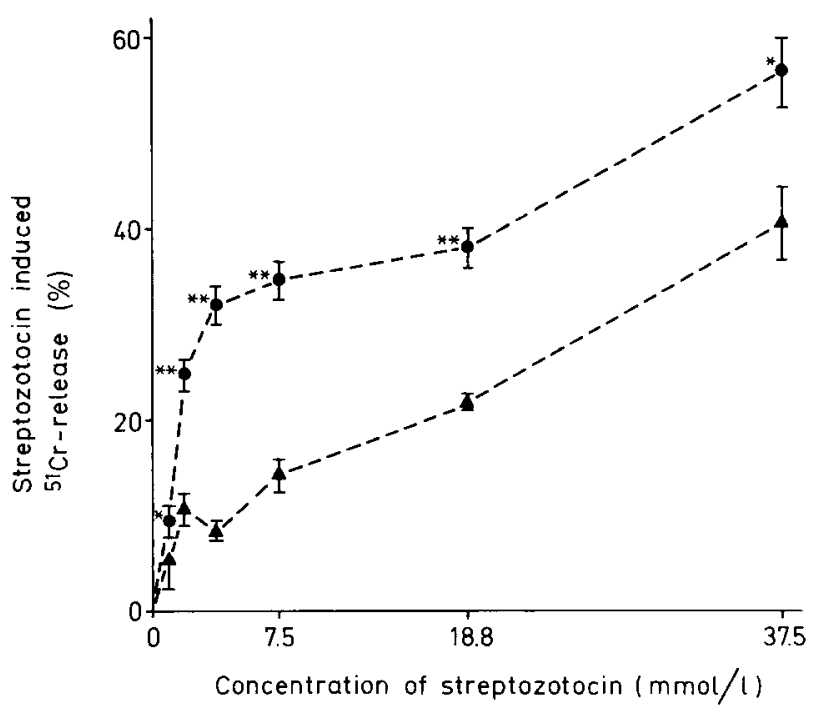

Fig.2. Streptozotocin induced ${ }^{51} \mathrm{Cr}-$-release (specific releâse) from islet cells prepared from male or female C3 D2 F1 mice, at increasing concentrations of the drug. The figure shows mean \pm SEM values of six individual observations. - : male cells; $\boldsymbol{\Delta}$ : female cells. Islet cells from male animals released more of the isotope compared with female cells $\left(* p<0.04\right.$ and $\left.{ }^{* *} p=0.001\right)$

was $7.1 \pm 0.8 \%(n=10)$. The difference between male and female islet cell response was significant $(p<0.005)$ and was also evident in a second series of experiments carried out over a wide concentration range of SZ (Fig. 2).

Islet cells from 2 week-old sexually immature animals were less sensitive to SZ. Thus mean values of specific release of ${ }^{51} \mathrm{Cr}$ in five independent experiments were $0.63 \pm 0.74 \%$ and $2.11 \pm 0.70 \%$ for male 
Table 2. Islet cells from sexually mature animals: cytotoxicity by streptozotocin

\begin{tabular}{lll}
\hline Sex & \multicolumn{3}{l}{ SZ induced ${ }^{51}$ Cr-release $(\%)$} \\
\cline { 2 - 3 } & - Hormone & + Hormone \\
\hline Male & $25.1 \pm 2.9(\mathrm{n}=7)$ & $23.4 \pm 2.1(\mathrm{n}=7)$ \\
Female & $14.8 \pm 3.0(\mathrm{n}=7)$ & $15.2 \pm 2.1(\mathrm{n}=7)$ \\
\hline
\end{tabular}

${ }^{51}$ Cr-prelabelled islet cells from 10 -week-old male or female C3 D2 F1 mice were incubated at $37^{\circ} \mathrm{C}$ for $4 \mathrm{~h}$ in tissue culture medium with or without $7.5 \mathrm{mmol} / 1$ streptozotocin. The incubations were performed with and without the addition of oestradiol $(1 \mu \mathrm{g} / \mathrm{ml})$ plus progesterone $(10 \mu \mathrm{g} / \mathrm{ml})$ or testosterone $(10 \mu \mathrm{g} / \mathrm{ml})$ to islet cells from male and female animals respectively.

The specific release of ${ }^{51} \mathrm{Cr}$ was higher from male cells than from female $(p<0.013)$, whereas the addition of sex hormones neither changed spontaneous isotope release (not shown) nor the specific release $(p>0.35)$

and female cells respectively. Sex did not significantly influence the release of the isotope $(p>0.11)$.

The presence of progesterone and oestradiol during the 4-h cytotoxicity assay did not change the susceptibility of islet cells from sexually mature male animals to SZ. Neither did the addition of testosterone alter the susceptibility to SZ of islet cells from sexually mature female animals (Table 2).

\section{Discussion}

The idea that immune mechanisms are involved in the development of experimental diabetes in mice, following multiple dosages of SZ, is supported by a protective effect of antilymphocyte serum [17] and total body irradiation (unpublished observation). Furthermore, athymic mice were resistant [18] and the resistance could be reversed by thymus transplantation [12]. Buschard and Rygaard [11] reported a diabetogenic effect of spleen cell transfer from SZ treated euthymic mice to athymic mice. However, several laboratories were unable to confirm this, [19-21, and our own unpublished observations]. Kiesel et al. [13] demonstrated lymphocytic infiltration of pancreatic islets in athymic recipients transferred with spleen cells from SZ treated animals, while hyperglycaemia was not observed. Paik et al. [12] also used athymic (nu/ $\mathrm{nu})$ and heterozygous euthymic $(+/ \mathrm{nu})$ mice and reported that animals transferred with spleen cells from SZ treated animals developed a slight glucose intolerance from days 4-20 following the transfer, this effect being dependent on the presence of $T$ lymphocytes.

We have used F1 hybrid mice, which are genetically and phenotypically uniform. The parental male, $\mathrm{DBA} / 2 \mathrm{~J}$ was apparently resistant to multiple low doses of SZ [22]. In our laboratory severe hyperglycaemia was not observed in this strain of mice in 121 days following multiple low doses of SZ (unpublished observation). The parental female, $\mathrm{C} 3 \mathrm{H} / \mathrm{Tif}$ has not been studied in this model of diabetes, but $\mathrm{C} 3 \mathrm{H} / \mathrm{Tif}$ males did not develop severe hyperglycaemia in 121 days after the SZ injections (unpublished observation) and $\mathrm{C} 3 \mathrm{H} / \mathrm{He}$ males were resistant [22]. In the F1 hybrid animals we found, however, a delayed onset of hyperglycaemia in the males, while female animals remained euglycaemic during the whole study period of 120 days. This pattern favours a polygenic mode of inheritance.

The sex influence might be explained by differences in the immune system. Thus $\mathrm{T} / \mathrm{B}$ lymphocyte ratios in spleen cells were higher in adult female mice than in males or testosterone treated females [23]. The sex influence on the pancreatic B cell susceptibility to SZ, however, may be independent of the immune system. Using the same type of hybrid mice of comparable age as in the studies in vivo, we found a stronger cytotoxic effect of SZ on isolated islet cells from male animals. This difference was reproducable and apparent also at different SZ concentrations. The differences in levels of specific release of the isotope might be explained by varying activity of the drug in different series of experiments.

A predisposing dominant gene on the $\mathrm{Y}$-chromosome has been shown to be associated with a spontaneous lupus-like syndrome in mice [24]. By analogy, the greater susceptibility of male mice to develop diabetes could thus simply be explained by a sex-dependent effect of SZ directly on the target cell. However, this interpretation is invalidated by the observation that islet cells from sexually immature animals, whether females or males, were less sensitive to SZ. A direct modulating influence of sex hormones on the target cell seems more likely, and would also explain the greater sensitivity to SZ in castrated male and testosterone treated female animals [8]. A sex-dependent cytotoxic effect could not, however, simply be mimicked by adding the hormones to the ${ }^{51} \mathrm{Cr}$-labelled islet cells, although the concentration and incubation conditions may not have been optimal here.

The idea of a direct influence of sex hormones was supported also by the results of spleen cell transfer experiments. The transfer of spleen cells from lowdose SZ treated female mice to syngeneic and immunosuppressed recipients produced hyperglycaemia only in recipients treated with testosterone. The latter developed a slight increase in blood glucose levels as well as impaired glucose tolerance. If sex hormones affect the reactivity of spleen cells, an effect of testosterone treatment on spleen cell donors would be expected. Such an effect was not demonstrated. 
Our findings are interesting in relation to the known excess of male children who develop Type 1 diabetes. The fact that the incidence in sexually immature children is relatively low, with a large incidence peak at the time of sexual maturation [2-4], suggests that the 'internal milieu' may play a role in modulating $B$ cell susceptibility to damage induced by environmental agents.

Acknowledgements. We thank H. Richter Olesen for expert technical assistance and T. Christensen for her careful preparation of the manuscript. This work was supported by a grant from Statens Laegevidenskabelige Forskningsråd, 512-8214.

\section{References}

1. Gundersen B (1927) Is diabetes of infectious origin? J Infect Dis 41: 197-202

2. Bloom A, Hayes TM, Gamble DR (1975) Register of newly diagnosed diabetic children. Br Med J 3: 580-583

3. Christau B, Kromann H, Ortved Andersen O, Christy M, Buschard K, Arnung K, Højland Kristensen I, Peitersen B, Steinrud J, Nerup J (1977) Incidence, seasonal and geographical patterns of juvenile-onset insulin-dependent diabetes mellitus in Denmark. Diabetologia 13:281-284

4. LaPorte RE, Fishbein HA, Drash AL, Kuller LH, Schneider BB, Orchard TJ, Wagener DK (1981) The Pittsburgh insulindependent diabetes mellitus (IDDM) registry. The incidence of insulin-dependent diabetes mellitus in Allegheny County, Pennsylvania (1965-1976). Diabetes 30: 279-284

5. Houssay BA (1951) Action of sex hormones on experimental diabetes. Br Med J 1: 505-510

6. Boucher DW, Hayashi K, Rosenthal J, Notkins AL (1975) Virus-induced diabetes mellitus III. Influence of the sex and strain of the host. J Infect Dis 131 : 462-466

7. Like AA, Rossini AA (1976) Streptozotocin-induced pancreatic insulitis: new model of diabetes mellitus. Science 193:415-417

8. Rossini AA, Williams RM, Appel MC, Like AA (1978) Sex differences in the multiple-dose streptozotocin model of diabetes. Endocrinology 103: 1518-1520

9. Maclaren NK, Neufeld M, McLaughlin JV, Taylor G (1980) Androgen sensitization of streptozotocin-induced diabetes in mice. Diabetes 29:710-716

10. Kromann H, Christy M, Lernmark $\AA$, Nerup J (1981) An in vitro, sex dependent, and direct cytotoxic effect of streptozotocin on pancreatic islet cells. Horm Metab Res 13:120-122

11. Buschard K, Rygaard J (1977) Passive transfer of streptozotocin induced diabetes mellitus with spleen cells. Acta Pathol Microbiol Scand $85: 469-472$
12. Paik SG, Fleischer N, Shin S-I (1980) Insulin-dependent diabetes mellitus induced by subdiabetogenic doses of streptozotocin: Obligatory role of cell-mediated autoimmune processes. Proc Natl Acad Sci 77:6129-6133

13. Kiesel U, Freytag G, Biener J, Kolb H (1980) Transfer of experimental autoimmune insulitis by spleen cells in mice. Diabetologia 19:516-520

14. Kiesel U, Kolb H, Freytag G (1981) Strain dependency of the transfer of experimental immune insulitis in mice. Clin Exp Immunol 43: 430-433

15. Kromann H, Lernmark Å, Vestergaard BF, Egeberg J, Nerup J (1979) The influence of the major histocompatibility complex (H-2) on experimental diabetes in mice. Diabetologia 16: 107-114

16. Kromann, H, Christy M, Egeberg J, Lernmark $\AA$, Nerup J, Richter-Olesen H (1980) Direct streptozotocin toxicity on dispersed mouse islet cells determined by ${ }^{51} \mathrm{Cr}$-release. Med Biol 58: $322-328$

17. Rossini AA, Williams RM, Appel MC, Like AA (1978) Complete protection from low-dose streptozotocin-induced diabetes in mice. Nature 276: 182-184

18. Buschard K, Rygaard J (1978) Is the diabetogenic effect of streptozotocin in part thymus-dependent? Acta Pathol Microbiol Scand 86: 23-27

19. Thurheyssen O, Jansen FK, Vialettes B, Vague P, Selam JL, Mirouze J (1979) Passive transfer of lymphocytes from diabetic man to athymic mouse. Lancet 1: 1291-92

20. Serra AS, Farndon JR, Shenton BK, Johnston IDA (1979) Passive transfer of lymphocytes from diabetic man to athymic mouse. Lancet 1: 1292

21. Beattie G, Lannom R, Lipsick J, Kaplan NO, Osler AG (1980) Streptozotocin-induced diabetes in athymic and conventional BALB/c mice. Diabetes 29: 146-150

22. Rossini AA, Appel MC, Williams RM, Like AA (1977) Genetic influence of the streptozotocin-induced insulitis and hyperglycemia. Diabetes 26:916-929

23. Dörner G, Eckert R, Hinz G (1980) Androgen-dependent sexual dimorphism of the immune system. Endokrinologie 76: $112-114$

24. Murphy ED, Roths JB (1979) A Y chromosome associated factor in strain BX SP producing accelerated autoimmunity and lymphoproliferation. Arthritis Rheum 22: 1188-1194

Received: 24 April 1981

and in revised form: 18 September 1981

Dr. H. Kromann

Steno Memorial Hospital

Niels Steensensvej

DK-2820 Gentofte, Denmark 